\title{
Passenger's Perception of Services of PT. Indonesian National Shipping Bima Branch
}

\author{
Rifai $^{1)}$, Nike Ardiansyah ${ }^{2)}$, Taufik irfadat ${ }^{3)}$ \\ ${ }^{1,2,3)}$ Sekolah Tinggi Ilmu Social dan Ilmu Politik (STISIP) Mbojo-Bima \\ *Coresponding Author \\ Email : rifai_ahmad69@yahoo.com
}

\begin{abstract}
Bima port is a vital necessity. The progress of crossing transportation in Bima port encourages the smooth flow of goods and services. The port of Bima since the Dutch colonial era has been known as a gateway for people to enter and leave various regions in the country. Various activities for distributing basic food items are increasingly massive and intensive, making it easier to provide food, board and clothing stocks in the Bima area. As a port, this area is quite strategic in supporting sea transportation and the distribution of goods and services for the local government and the people of Bima. The method used is descriptive quantitative with a population of all employees and the public who receive services, the number of samples is 30 random sampling respondents. As a result, $13.15 \%$ of respondents answered that they were very satisfied that the distribution of basic food items was getting more massive, then 44.85 percent of respondents answered that they were satisfied, and respondents who answered quite satisfied were $42.00 \%$ and respondents who answered dissatisfied were 0.00\%. Bima Port supports sea transportation and the flow of goods and services distribution for the local government and Bima community
\end{abstract}

Keywords: Perception, Passenger, Service

\section{INTRODUCTION}

Permenhub number 50 of 2021 concerning the operation of seaports Article 1 states that a port is a place consisting of land and/or waters with certain boundaries as a place for government activities and business activities that are used as a place for ships to lean on, get on and off passengers, and/or loading and unloading of goods, in the form of terminals and ship berths equipped with shipping safety and security facilities and port support activities as well as intra and intermodal transportation. Meanwhile, Article 4 states that a sea port is a port that can be used to serve sea transportation activities and/or ferry transportation located at sea or on a river.

PT. Pelayaran Nasional (PELNI) Indonesia is one of the state-owned companies that has the main business of providing sea transportation transportation services which include passenger transportation services and inter-island cargo transportation services. The era of transparency and the development of information technology has made society more critical. Conditions like this require agencies/organizations to accommodate and anticipate the public's desire to obtain information. The development of information technology has given birth to a fairly rapid development in the print and electronic mass media.

The proliferation of various mass media and the rapid flow of information is not a guarantee that it will enlighten the public, even in some cases it is confusing. Meanwhile, there is an opinion that with the development of information technology, people can directly and quickly get information and are no longer managed by the government. The government's role is more emphasized only as a policy maker, regulation and facilitation. The current era of globalization requires companies to improve services professionally according to their respective fields. Changes in technology and the rapid flow of information have encouraged companies to produce products or services that can meet the needs and desires of consumers, 
so that consumers are satisfied with what they have received from the company. There are many ways that companies can do in meeting the needs and desires of consumers, one of which is by giving a good impression/image in terms of products and services to consumers.

Performance targets are a specific statement that explains the results to be achieved by whom and what to be achieved are completed, can be calculated, achievements can be observed, and can be measured. Performance targets include: performance improvement, employee development, compensation decisions, and communication skills (Sinambela, 2012). State-Owned Enterprises (BUMN) in Indonesia are very influential in the development of the business world and the community in running their business, because most of these government-owned companies have monopolized several business fields that regulate the lives and needs of many people. Therefore, in regulating and running their business, BUMN is regulated and managed by the government because it is closely related to the fate of the Indonesian people. an increase or decrease in performance is not directly influenced by the work environment, a good work environment does not directly improve employee performance, because employees increase their performance not because of a good work environment but there are other factors that can improve their performance (Kartono, Asnawi, \& Susilawati, 2019

As an archipelagic region, crossing transportation at the ports is the scope of work of PT. PELNI Bima Branch is a vital necessity in supporting regional development. The progress of crossing transportation can encourage the smooth flow of goods and services and increase human mobility, especially in remote areas. The port of Bima since the Dutch colonial era has been known as a gateway for people to enter and leave various regions in the country, this event continues until now and has been connected to the eastern part of Indonesia. Various activities for distributing basic goods are increasingly massive and intensive so as to facilitate the supply of stock of materials within the region. The area is strategic enough to make the port a sensual icon for the regional government and society. Human resource development is one aspect of human resource management. Human resource development is an important business in every organization because development activities can create quality employees so that the organization can be more advanced and developed (Nikmah, Arief, 2020)

Advances in transportation technology have created and increased the degree of accessibility of the potentials of natural resources and market area. Natural resources that were not previously utilized will be affordable and can be processed. Transportation is also related to productivity. Advances in transportation bring increased mobility of people, factors of production and marketed processed products. Higher mobility means faster movement and equipment that is reflected in smooth distribution and shorter time required to process materials and move them from places where the materials are less useful to places where the benefits are greater. Higher mobility means more productive. According to revelation PA (2015), there are 2 factors in the service at the port passenger terminal, the first factor is convenience, security, convenience from the stop location to the terminal; The second factor is the comfort and safety factor from the terminal to the ship's entrance. The safety aspect at the stop location in the port area needs to be improved to improve the quality of service at the passenger terminal at the port. Meanwhile, according to Kotler (2007) is any action or activity that can be offered by a party to another party that is essentially intangible and does not result in any ownership. Then according to Gronroos (in Tjiptono, 2005) that is a process consisting of a series of intangible activities that usually (but not always) occur in interactions between customers and employees, services and physical resources or goods and service provider systems that are provided as a solution to the problem customer. Dedy A. (2014) Ports as a service industry are essentially services in the form of services provided by port companies to their customers, they must have 
a certain quality or service quality, therefore service companies (port companies) should measure the level of customer satisfaction.

\section{RESEARCH METHODS}

The method used is descriptive quantitative, with a population of all employees and the public who receive services then the number of samples is 30 respondents who are determined randomly by giving questionnaires to all samples that have been previously determined by the researcher, data is also obtained with the results of the documentation contained in research locus. Data collection is very important to do as a supporter and argumentative reinforcement, therefore data collection is in the form of documentation as a comparison between research results and developments in the field, both previous and ongoing.

\section{RESULTS AND DISCUSSION}

\section{Passenger Perceptions in the Dimension of Reality (reliability) of the Service Officers of PT PELNI Bima Branch.}

There are two dimensions of reliability that will be discussed, the first is the accuracy of the ship's departure and arrival, and the second is the ticket service system. The results of the research on the reliability dimension as referred to, Reliability is the ability to provide services in accordance with the promises offered. Indicators of reliability are the punctuality of ship arrivals and departures and the ticket service system.

Table 1. Passenger Perceptions in the Dimension of Reality.

\begin{tabular}{llcc}
\hline No & Type of Assessment & Frequency & Percentage \\
\hline 1 & Very good & 7 & $23,00 \%$ \\
2 & Well & 14 & $49,75 \%$ \\
3 & Pretty good & 9 & $27,25 \%$ \\
4 & Not good & 0 & $0,00 \%$ \\
& total & 30 & 100 \\
\hline
\end{tabular}

Source: processed questionnaire results, 2021

Of the 30 samples who have provided answers to the distributed questionnaires, research data is obtained that $24 \%$ of respondents chose very good answers, $49.75 \%$ of respondents who answered good, and respondents who answered quite well $22.25 \%$ chose and for answers Not Good as much as $0.00 \%$.

Table 2. Prospective Passengers' Perceptions Of Employee Reliability

\begin{tabular}{llcc}
\hline No & Type of Assessment & Frequency & Percentage \\
\hline 1 & Very good & 36 & $36,00 \%$ \\
2 & Well & 47 & $47,00 \%$ \\
3 & Pretty good & 17 & $17,00 \%$ \\
4 & Not good & 0 & $0,00 \%$ \\
& total & 100 & 100 \\
\hline
\end{tabular}

Source: Bima Branch Pelni Office, 2020 
Based on the answers from respondents who chose very good answers, namely $36.00 \%$, then respondents who chose good answers were $47.00 \%$, and respondents who had chosen quite good answers were $17.00 \%$, and respondents who chose not good answers were $0,00 \%$. This shows that the services that have been provided are good according to the percentage of respondents' answers.

\section{Passenger Perceptions in Responsiveness Dimensions (responsiveness) to the Service Officers of PT PELNI Bima Branch.}

Responsiveness, namely the response or alertness of employees in helping customers and providing fast and responsive service, including the alertness of employees in handling transactions, and handling complaints. When prospective passengers have difficulty in accessing information about the cruise according to the schedule and destination of the crossing. Therefore, the responsiveness of employees to these matters is very important. Especially when prospective passengers are ambiguous about the schedule or purchase of ship tickets.

Table 3. Passenger Perceptions in Responsiveness Dimensions

\begin{tabular}{llcc}
\hline No & Type of Assessment & Frequency & Percentage \\
\hline 1 & Very good & 9 & $29,00 \%$ \\
2 & Well & 12 & $42,00 \%$ \\
3 & Pretty good & 9 & $29,00 \%$ \\
4 & Not good & 0 & $0,00 \%$ \\
& total & 30 & 100 \\
\hline
\end{tabular}

Source: processed questionnaire results, 2020.

Based on the answers from respondents who have chosen very good answers, that is $29.00 \%$, then respondents who choose good answers are $42.00 \%$, and respondents who have chosen quite good answers are $29.00 \%$, and respondents who choose not good answers $0,00 \%$. This shows that the responsiveness of the employees who have been given is good according to the percentage of respondents' answers.

Table 4. Responsiveness Dimensions

\begin{tabular}{llcc}
\hline No & Type of Assessment & Frequency & Percentage \\
\hline 1 & Very good & 26 & $26,00 \%$ \\
2 & Well & 47 & $47,00 \%$ \\
3 & Pretty good & 27 & $27,00 \%$ \\
4 & Not good & 0 & $0,00 \%$ \\
& total & 100 & 100 \\
\hline
\end{tabular}

Source: Bima Branch Pelni Office, 2021

Based on the answers from respondents who have chosen very good answers, namely $26.00 \%$, then respondents who chose good answers are $47.00 \%$, and respondents who have chosen quite good answers are $27.00 \%$, and respondents who chose not good answers $0,00 \%$. This shows that the responsiveness of the employees who have been given is good according to the percentage of respondents' answers. 


\section{How are Passenger Perceptions Dimensionally Completed Facilities for Service Officers PT PELNI Bima Branch.}

Meanwhile, the guarantee for the completeness of passenger ship facilities is considered to be less good. The completeness of the facilities provided is in accordance with what was promised to consumers, but according to them the current condition of the facilities needs to be repaired and maintained. The knowledge and skills of employees are considered good because consumers believe that both employees and ship attendants have received previous training so that they can provide information to passengers.

Table 5. Perceptions Dimensionally Completed Facilities for Service

\begin{tabular}{llcc}
\hline No & Type of Assessment & Frequency & Percentage \\
\hline 1 & Very good & 4 & $18,00 \%$ \\
2 & Well & 15 & $50,75 \%$ \\
3 & Pretty good & 11 & $31,25 \%$ \\
4 & Not good & 0 & $0,00 \%$ \\
& total & 30 & 100 \\
\hline
\end{tabular}

Source: processed questionnaire results, 2020.

The answers from respondents who have chosen very good answers are $18.00 \%$, then respondents who choose good answers are $50.75 \%$, and respondents who have chosen quite good answers are $31.25 \%$, and respondents who chose not good answers are $0.00 \%$. This shows that the facilities that have been provided that have been provided are good according to the percentage of respondents' answers. However, respondents gave sufficient answers with a large percentage of data compared to very good answers.

Table 6. Dimensionally Completed Facilities

\begin{tabular}{llcc}
\hline No & Type of Assessment & Frequency & Percentage \\
\hline 1 & Very good & 16 & $16,00 \%$ \\
2 & Well & 47 & $47,00 \%$ \\
3 & Pretty good & 37 & $37,00 \%$ \\
4 & Not good & 0 & $0,00 \%$ \\
& total & 100 & 100
\end{tabular}

Source: Bima Branch Pelni Office, 2021

The answers from respondents who have chosen very good answers are $16.00 \%$, then respondents who chose good answers are $47.00 \%$, and respondents who have chosen quite good answers are $37.00 \%$, and respondents who chose not good answers are $0,00 \%$. This shows that the facilities that have been provided that have been provided are good according to the percentage of respondents' answers. However, respondents gave sufficient answers with a large percentage compared to very good answers.

How are Passengers' Perceptions of Employee Work Productivity towards Service Officers of PT PELNI Bima Branch.

Productivity basically includes attitudes and abilities that are oriented towards continuous improvement, and have the view that today's performance must be better than yesterday's performance and tomorrow's performance must be better than today's achievement. This pattern of behavior will encourage subordinates to always try to improve their work, as a stimulus to always do good. enough to have skills in carrying out their duties. The data obtained shows that being an employee is enough to guarantee to be able to work 
professionally. Increasing high performance productivity and increasing professionalism in work, will always be related to performance measures or standards

Table 7. Passengers' Perceptions of Employee Work Productivity

\begin{tabular}{llcc}
\hline No & Type of Assessment & Frequency & Percentage \\
\hline 1 & Very good & 6 & $22,00 \%$ \\
2 & Well & 15 & $50,75 \%$ \\
3 & Pretty good & 9 & $27,25 \%$ \\
4 & Not good & 0 & $0,00 \%$ \\
& total & 30 & 100 \\
\hline
\end{tabular}

Source: processed questionnaire results, 2020.

The answers from respondents who have chosen very good answers are $22.00 \%$, then respondents who chose good answers are $50.75 \%$, and respondents who have chosen quite good answers are $27.25 \%$, and respondents who chose not good answers are 0,00\%. This shows that the performance of the employees who have been given is good according to the percentage of respondents' answers. However, respondents gave sufficient answers with a large percentage compared to very good answers.

Table 8. Perceptions of Employee Work Productivity

\begin{tabular}{llcc}
\hline No & Type of Assessment & Frequency & Percentage \\
\hline 1 & Very good & 18 & $18,00 \%$ \\
2 & Well & 47 & $47,00 \%$ \\
3 & Pretty good & 34 & $34,00 \%$ \\
4 & Not good & 0 & $0,00 \%$ \\
& total & 100 & 100 \\
\hline
\end{tabular}

Source: Bima Branch Pelni Office, 2021

The answers from respondents who have chosen very good answers are $18.00 \%$, then respondents who choose good answers are $47.00 \%$, and respondents who have chosen quite good answers are $34.00 \%$, and respondents who chose not good answers are $0,00 \%$. This shows that the performance of the employees who have been given is good according to the percentage of respondents' answers. However, respondents gave sufficient answers with a large percentage compared to very good answers.

How are Passengers' Perceptions of Employee attitudes and behavior towards Service Officers of PT PELNI Bima Branch.

This attitude comes from their perception of their work and this depends on the level of intrinsic and extrinsic outcomes and how workers/employees perceive these outcomes and reflect their feelings towards their work.

Table 9. Perceptions of Employee attitudes and behavior

\begin{tabular}{llcc}
\hline No & Type of Assessment & Frequency & Percentage \\
\hline 1 & Very good & 9 & $27,25 \%$ \\
2 & Well & 15 & $50,75 \%$ \\
3 & Pretty good & 6 & $12,00 \%$ \\
4 & Not good & 0 & $0,00 \%$ \\
& total & 30 & 100 \\
\hline
\end{tabular}

Source: processed questionnaire results, 2020. 
The answers from respondents who have chosen very good answers are $27.25 \%$, then respondents who choose good answers are $50.75 \%$, and respondents who have chosen quite good answers are $12.00 \%$, and respondents who choose not good answers are $0,00 \%$. This shows that the employee ethics that have been given are good according to the percentage of respondents' answers.

Table 10. Perceptions of Employee attitudes and behavior

\begin{tabular}{llcc}
\hline No & Type of Assessment & Frequency & Percentage \\
\hline 1 & Very good & 22 & $22,00 \%$ \\
2 & Well & 47 & $47,00 \%$ \\
3 & Pretty good & 31 & $31,00 \%$ \\
4 & Not good & 0 & $0,00 \%$ \\
& total & 100 & 100 \\
\hline
\end{tabular}

Source: Bima Branch Pelni Office, 2021

The answers from respondents who have chosen very good answers are $22.00 \%$, then respondents who chose good answers are $47.00 \%$, and respondents who have chosen quite good answers are $31.00 \%$, and respondents who chose not good answers are $0,00 \%$. This shows that the employee ethics that have been given are good according to the percentage of respondents' answers.

\section{CONCLUSION}

The perception of prospective passengers on employee performance is quite good, employee abilities and employee morale are good, measuring employee compliance with existing regulations is good: the imposition of fees / service rates is very good, timeliness of service and service procedures or procedures are quite good. The performance of employees in providing services to the community is in a fairly good category with indicators of attendance, service transparency and service results, these results are based on data processing from respondents' answers, the results are $13.15 \%$ ofrespondents answered that they were very satisfied that the distribution of basic food items was getting more massive, then 44.85 percent of respondents answered that they were satisfied, and respondents who answered quite satisfied were $42.00 \%$ and respondents who answered dissatisfied were $0.00 \%$. Bima Port supports sea transportation and the flow of goods and services distribution for the local government and Bima community.

\section{REFERENCES}

Anggrahini, Wahyu P., 2010. Factors that Affecting Community Satisfaction with Ro-Ro Sea Freight Service (Case Study Banjarmasin Harbor, Research Journal Sea Transportation, Volume 12 Number 4 December 2010, Jakarta;

Bima Branch Pelni Office

Dedy A. 2014, QUALITY SERVICE IMPROVEMENT OF PASSENGER TERMINAL IN PORT OF AMBON. Transportation Research News, Volume 26, Number 10, October 2014 
Kartono, Asnawi, and Susilawati (2019). The Influence of Work Environment and Motivation on Job Satisfaction and Its Impact on Employee Performance at the Land Office of Merangin Regency, Jambi Province. J-MAS (Journal of Management and Science), 4(1), 142-155 ISSN 2541 -6243 (Online), ISSN 2541-688X DOI 10.33087/jmas.v4i1.82.

Kotler, Philip., 2007. Service Marketing Management in Indonesia, analysis of Planning, Implementation, and Controlling, Translation Susanto, AB., Andi Publishers, Salemba Empat Publishers, Jakarta;

Nikmah Hayati, Arief Purwanto, 2020. THE IMPACT OF HUMAN RESOURCES AND PERSONALITY DEVELOPMENT ON COMPETENCE AND PERFORMANCE (Study on Employees of the Pasuruan City Environment, Hygiene and Parks Service). Journal of Management Science Volume 6, Number 2, July 2020

Permenhub number 50 of 2021 concerning the operation of seaports

Sinambela, Lijan Poltak. (2018). Employee Performance Measurement Theory and Implications. Yogyakarta: Graha Ilmu.

Tjiptono, Fandy., and Chandra, Gregory., 2005. Service Quality Satisfaction, Andi Publisher, Yogyakarta; 